\title{
SISTEM INFORMASI PENDATAAN PAJAK DAERAH PADA BADAN KEUANGAN DAERAH KOTA CIREBON BERBASIS WEB MENGGUNAKAN METODE $S E L F$ ASSESSMENT SYSTEM
}

\author{
Rizky Ramadhan Fatturohman ${ }^{1}$, Reza Ilyasa ${ }^{2}$ \\ Universitas Catur Insan Cendekia Cirebon \\ Jl. Kesambi No. 202, Kota Cirebon \\ e-mail: ramadhanrizky3@gmail.com ${ }^{1}$, reza.ilyasa@cic.ac.id ${ }^{2}$
}

\begin{abstract}
ABSTRAK
Pajak Daerah merupakan sumber pendapatan daerah yang penting untuk membiayai dalam memantapkan otonomi daerah yang nyata, dinamis, dan bertanggung jawab. Sistem pencatatan pendataan wajib pajak baru belum menggunakan teknologi, sehingga sering terjadi pendataan data yang sama. Dengan sistem yang masih manual, dokumen penting mudah hilang ataupun rusak dan mengulang pencatatan wajib pajak, serta petugas wajib pajak mengalami kesulitan dalam menjalankan kegiatan. Maka dari itu dibutuhkan pemanfaatan sistem informasi pendataan pajak daerah untuk dapat membantu melakukan penyimpanan data Perusahaan, Ketetapan Pajak, Laporan Tagihan Pajak, Laporan Kurang Bayar Pajak, dan Laporan Setoran Pajak. Sistem Informasi Pendataan Pajak Daerah dapat digunakan oleh Petugas Bagian Pengelolaan Data untuk mengelola data informasi pajak reklame, pajak restoran, perusahaan, dan ketetapan pajak daerah. Pada Bagian Pelaporan dapat mengkonfirmasi apabila wajib pajak sudah membayar Tagihan Pajak, Kurang Bayar Pajak, dan Setoran Pajak. Kemudian Kepala Bidang Pajak Daerah menerima laporan informasi data tersebut melalui Sistem Informasi Pendataan Pajak Daerah. Perancangan Sistem Informasi Pendataan Pajak Daerah menggunakan bahasa PHP Hypertext Prepocessor dan perangkat lunak MySql sebagai media penyimpanan, untuk rancangan sistem terkomputerisasi disusun dalam Use case, diagram Activity, Sequence diagram, Class diagram. Hasil penelitian ini adalah Sistem Informasi Pendataan Pajak Daerah yang berfungsi untuk mengelola pendataan pajak daerah dalam kegiatan wajib pajak. Hasil implementasi tersebut menghasilkan output berupa laporan data perusahaan, data ketetapan pajak daerah, laporan tagihan pajak, laporan kurang bayar pajak, dan laporan setoran pajak. Berdasarkan output, dapat disimpulkan bahwa Sistem Informasi Pendataan Pajak Daerah dapat diterapkan pada Badan Keuangan Daerah Kota Cirebon.
\end{abstract}

Kata Kunci : Sistem, Informasi, Pendataan, Pajak, Daerah

\begin{abstract}
Local taxes are an important source of regional income to finance in strengthening real, dynamic, and responsible regional autonomy. The new taxpayer data recording system has not used technology, so that the same data collection often occurs. With a system that is still manual, important documents are easily lost or damaged and the taxpayers' registration is repeated, and taxpayers experience difficulties in carrying out activities. Therefore, it is necessary to use the local tax data collection information system to help store company data, tax assessments, tax bill reports, tax underpayment reports, and tax payment reports. The Regional Tax Data Collection Information System can be used by the Data Management Officer to manage data on advertisement tax information, restaurant taxes, companies, and local tax assessments. The Reporting Section can confirm if the taxpayer has paid Tax Bills, Tax Underpayments, and Tax Payments. Then the Head of the Regional Tax Division receives the data information report through the Regional Tax Data Collection Information System. The design of the Local Tax Data Collection Information System uses the PHP language Hypertext Prepocessor and MySql software as storage media, for computerized system designs compiled in Use cases, Activity diagrams, Sequence diagrams, Class diagrams. The result of this research is a Regional Tax Data Collection Information System which functions to manage local tax data collection in taxpayer activities. The results of this implementation produce output in the form of company data reports, local tax assessment data, tax bill reports, tax underpayment reports,
\end{abstract}


and tax payment reports. Based on the output, it can be concluded that the Regional Tax Data Collection Information System can be applied to the Regional Financial Board of Cirebon City.

\section{Keywords: TAM, information academic system, Polsri}

\section{Pendahuluan}

Pajak Daerah merupakan sumber pendapatan daerah yang penting untuk membiayai dalam memantapkan otonomi daerah yang nyata, dinamis, dan bertanggung jawab. Menurut Undang - Undang Nomor 32 Tahun 2004 tentang Pemerintah Daerah Pasal 1, otonomi daerah adalah hak, wewenang, dan kewajiban daerah otonom untuk mengatur dan mengurus sendiri urusan pemerintahan dan kepentingan masyarakat setempat sesuai dengan peraturan perundang - undangan (Kacaribu, M. N. S. 2016).

Sistem Pajak Restoran dan Pajak Reklame menggunakan sistem yang tergantung pada kesadaran pajak dari masing-masing wajib pajak. Pada hal ini disebut sebagai sistem self assessment dimana setiap wajib pajak diberi kepercayaan untuk menghitung, memperhitungkan, membayar, dan melaporkan sendiri pajak yang terutang sesuai dengan ketentuan peraturan perundang-undangan perpajakan. Apabila wajib pajak restoran dan pajak reklame tidak membayarkan pajak yang terutang maka akan dilakukan penagihan utang pajak (Fitriya, D.T 2015).

Pada pajak daerah terdiri dari dua pelayanan, yaitu; pajak daerah 1 terdiri dari pajak reklame, pajak hotel, pajak restoran, pajak wallet, pajak penerangan jalan, pajak air tanah, pajak parkir, pajak hiburan. Dan pajak daerah 2 terdiri dari Pajak Bea Perolehan Hak Atas Tanah dan Bangunan (BPHTB), dan Pajak Bumi dan Bangunan (PBB).

Dalam hal ini peran serta masyarakat Wajib Pajak dalam memenuhi kewajiban pembayaran pajak berdasarkan ketentuan perpajakan masih diharapkan, tetapi dalam kenyataannya masih banyak dijumpai adanya tunggakan pajak sebagai akibat tidak dilunasinya utang pajak yang sebagaimana mestinya. Maka tunggakan pajak yang dimaksud perlu dilaksanakan tindakan penagihan pajak yang mempunyai hukum yang memaksa (Fitriani, E., Lidyah, R., \& Fajriyana, I. 2014).

Dari uraian Pajak Restoran dan Pajak Reklame dan lainnya merupakan potensi yang paling besar dalam pembangunan daerah Kota Cirebon yang dapat dilihat dari peningkatan Pendapatan Asli Daerah. Oleh Karena itu sebagai lembaga pemerintah diperlukan "Sistem Informasi Pendataan Pajak Daerah Pada Badan Keuangan Daerah Kota Cirebon Berbasis Web Menggunakan Metode Self Assessment System".

\section{KAJIAN PUSTAKA}

\subsection{Sistem Informasi}

Menurut Krismiaji dalam bukunya yang berjudul Sistem Informasi Akuntansi. Informasi adalah data yang telah diorganisasi, dan telah memiliki kegunaan dan manfaat. (Krismiaji , 2015). Menurut Krismiaji dalam bukunya yang berjudul "Sistem Informasi Akuntansi. Sistem informasi adalah cara-cara yang diorganisasi untuk mengumpulkan, memasukkan dan mengolah serta menyimpan data, dan cara-cara yang diorganisasi untuk menyimpan, mengelola, mengendalikan, dan melaporkan informasi sedemikian rupa sehingga sebuah organisasi dapat mencapai tujuan yang telah ditetapkan. (Krismiaji, 2015).

\subsection{Pajak Daerah}

Pajak Daerah merupakan sumber pendapatan daerah yang sangat penting. untuk membiayai daerah dalam memantapkan otonomi daerah yang nyata, serasi, dinamis, dan bertanggung jawab. Menurut Undang Undang Nomor 32 Tahun 2004 tentang Pemerintah Daerah Pasal 1, otonomi daerah adalah hak, wewenang, dan kewajiban daerah otonom untuk mengatur dan mengurus sendiri urusan pemerintahan dan kepentingan masyarakat setempat sesuai dengan peraturan perundang - undangan (Kacaribu, M. N. S. 2016).

Sistem Informasi Pendataan Pajak Daerah Pada Badan Keuangan Daerah Kota Cirebon Berbasis Web Menggunakan Metode Self Assessment System -(Reza Ilyasa, Rizky Ramadhan Fatturohman) 


\subsection{Pajak Restoran}

Pajak Restaurant Sesuai dengan Peraturan Walikota Cirebon Nomor 50 Tahun 2012 adalah Pajak untuk fasilitas penyedia makanan dan/atau minuman dengan dipungut bayaran, yang mencakup rumah makan, kafetaria, kantin, warung, bar, dan sejenisnya termasuk jasa boga/katering.

\subsection{Pajak Reklame}

Menurut peraturan Walikota Cirebon Nomor 38 Tahun 2014, reklame adalah benda, alat, perbuatan atau media yang menurut corak ragamnya untuk bertujuan komersial, memujikan suatu barang, jasa atau orang, ataupun untuk menarik perhatian umum kepada suatu barang, jasa atau orang yang ditempatkan atau yang dapat dilihat, dibaca dan didengar dari suatu tempat umum, kecuali yang dilakukan oleh pemerintah.

\subsection{Self Assessment System}

Menurut Rimsky K. Judisseno menjelaskan bahwa, self assesment system diberlakukan untuk memberikan kepercayaan yang sebesar-besarnya bagi masyarakat guna meningkatkan kesadaran dan peran masyarakat dalam menyetorkan pajaknya. Konsekuensinya, masyarakat harus benar-benar mengetahui tata cara perhitungan pajak dan segala sesuatu yang berhubungan dengan peraturan pemenuhan perpajakan.

\subsection{Badan Keuangan Daerah Kota Cirebon}

Badan Keuangan Daerah Kota Cirebon adalah sebuah instansi pemerintah yang mengelola dana pajak daerah di wilayah Cirebon yang bertempat Jl. Pengampon No.4 Lemahwungkuk Kota Cirebon. Dibentuk berdasarkan Peraturan Daerah Kota Cirebon Nomor 07 Tahun 2016 tentang Pembentukan dan Penyusunan perangkat Daerah Kota Cirebon serta Peraturan Walikota Nomor 65 Tahun 2016 tentang Kedudukan, Struktur Organisasi, Tugas dan Fungsi, serta Tata Kerja Badan Keuangan Daerah Kota Cirebon.

\subsubsection{Struktur Organisasi}

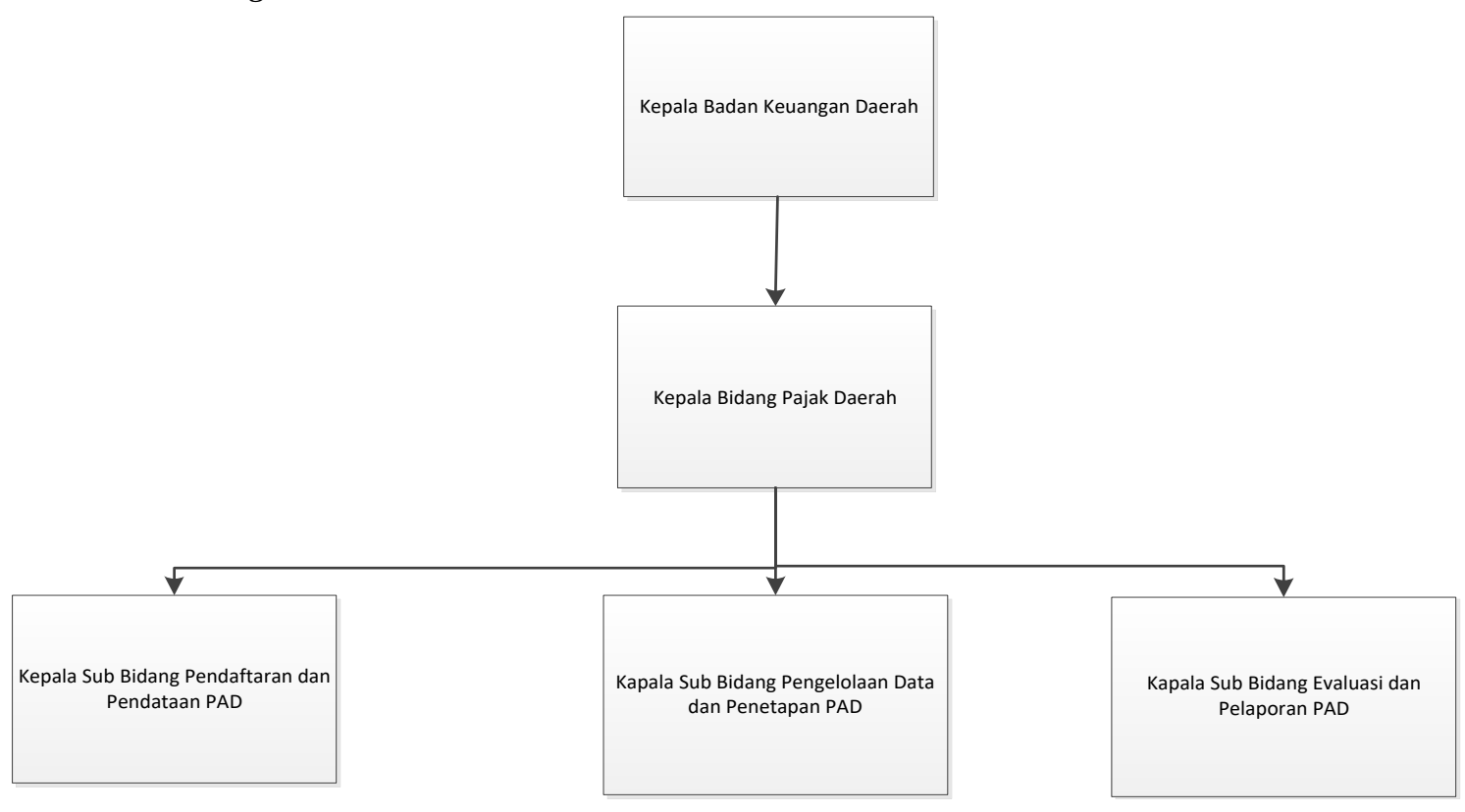

Sumber : Kantor Badan Keuangan Daerah Kota Cirebon

Gambar 1. Struktur Organisasi Badan Keuangan Daerah

\section{PERANCANGAN SISTEM}

3.1 Use Case Diagram

3.1.1 Wajib Pajak 


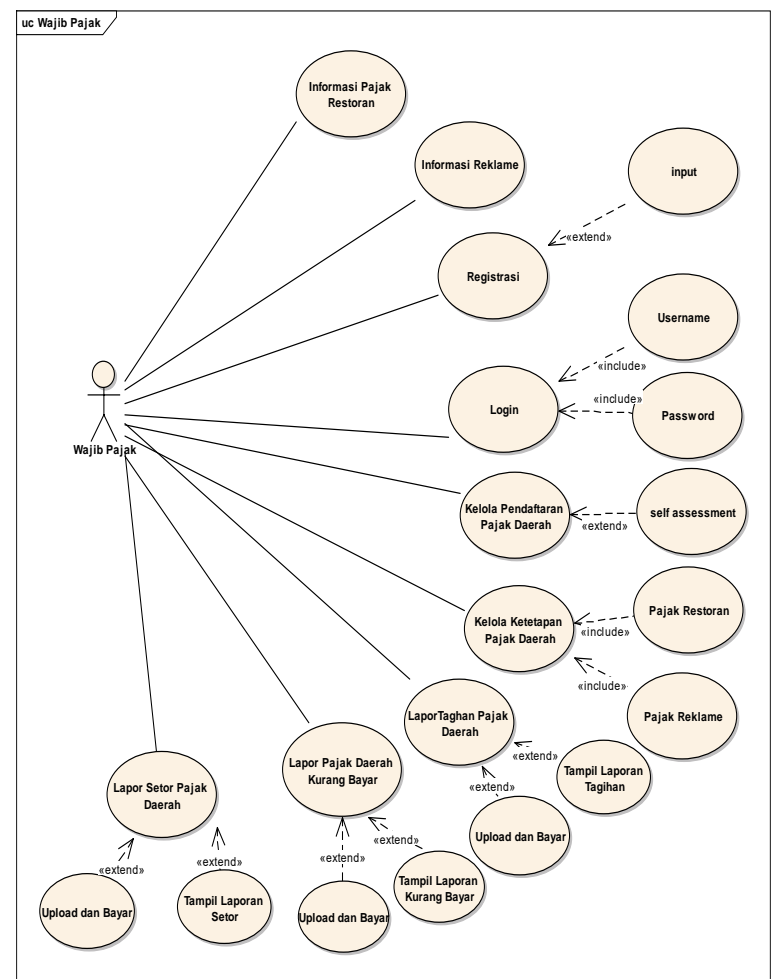

Gambar 2. Use Case Diagram Wajib Pajak

3.2 Activity Diagram 3.2.1 Wajib Pajak

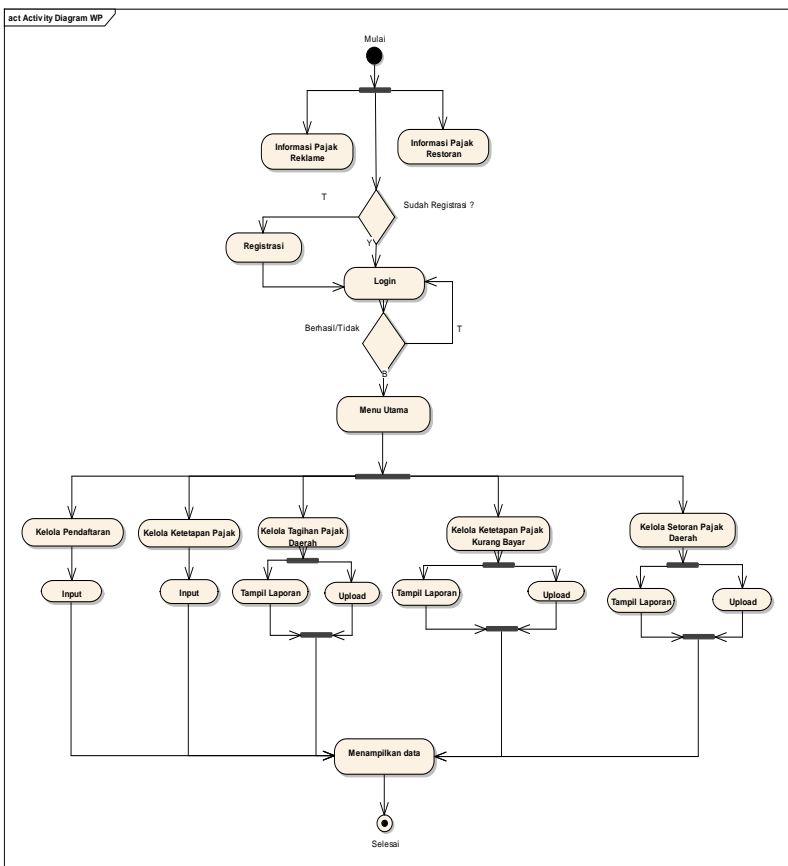

Gambar 3. Activity Diagram Wajib Pajak

Sistem Informasi Pendataan Pajak Daerah Pada Badan Keuangan Daerah Kota Cirebon Berbasis Web Menggunakan Metode Self Assessment System -(Reza Ilyasa, Rizky Ramadhan Fatturohman) 


\subsection{Sequence Diagram}

3.3.1 Wajib Pajak

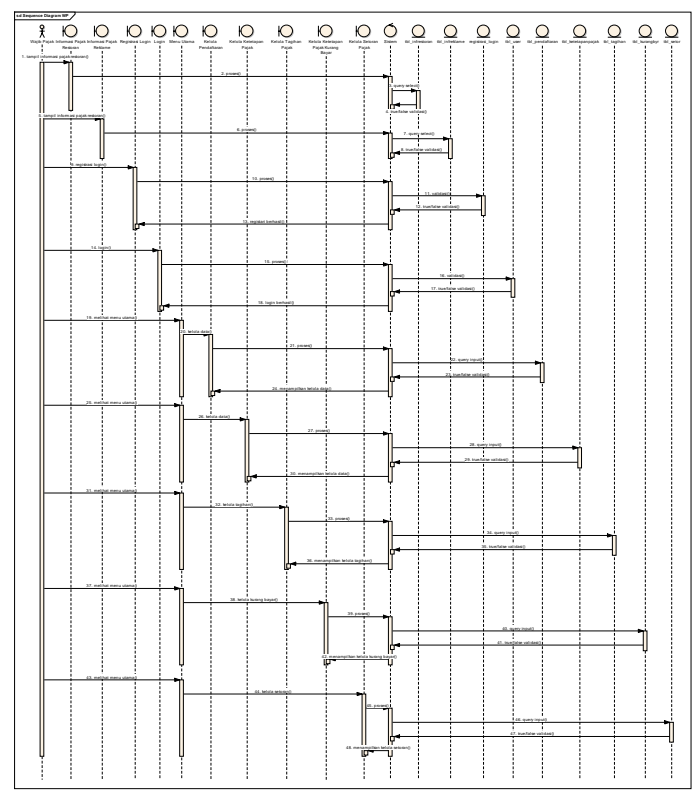

Gambar 4. Sequence Diagram Wajib Pajak

\subsection{Class Diagram}

3.4.1 Wajib Pajak

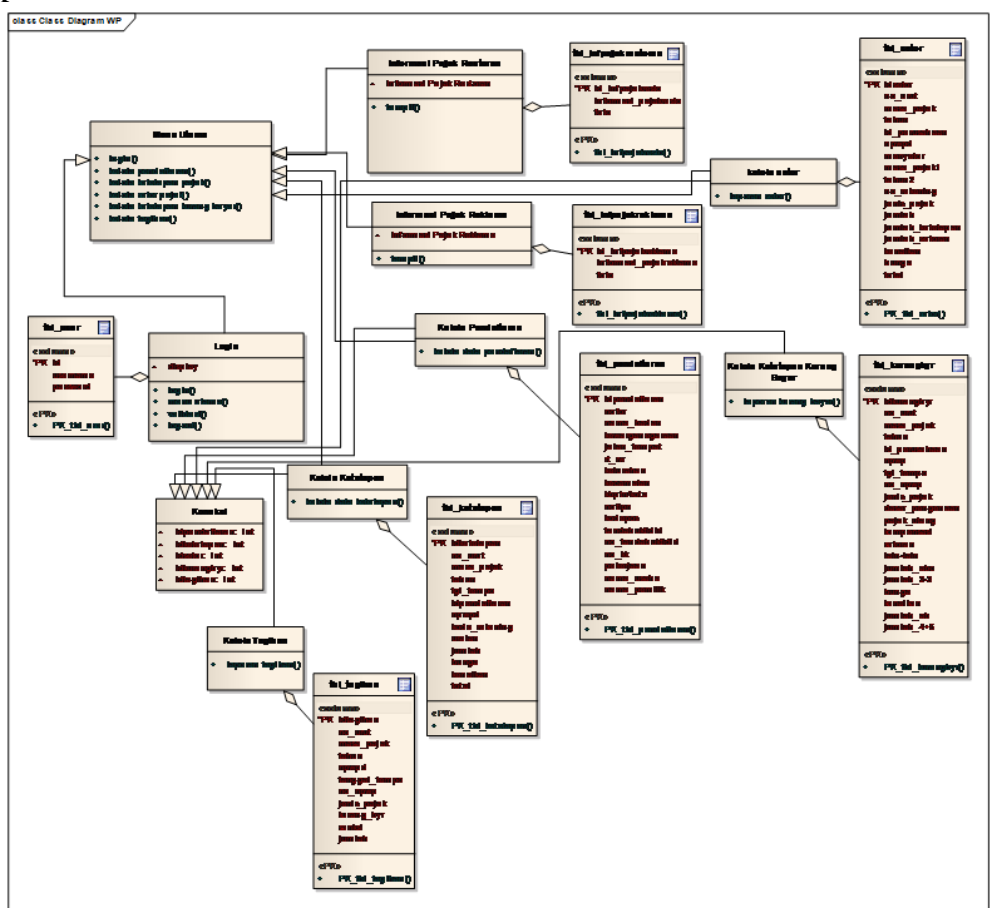

Gambar 5. Class Diagram Wajib Pajak 


\section{HASIL PENELITIAN}

\subsection{Tampilan Informasi Pajak Restoran}

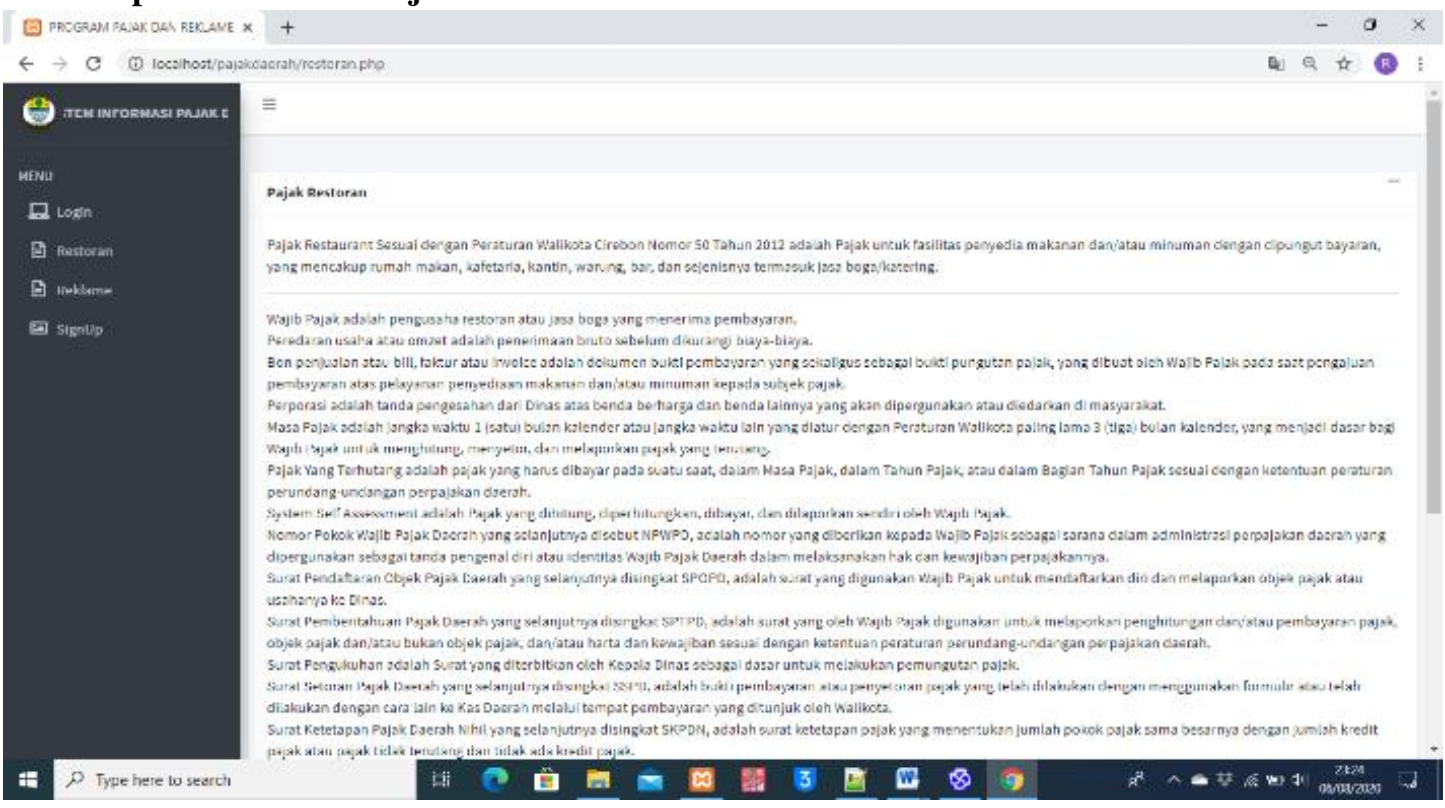

Gambar 6. Tampilan Informasi Pajak Restoran

\subsection{Tampilan Informasi Pajak Reklame}

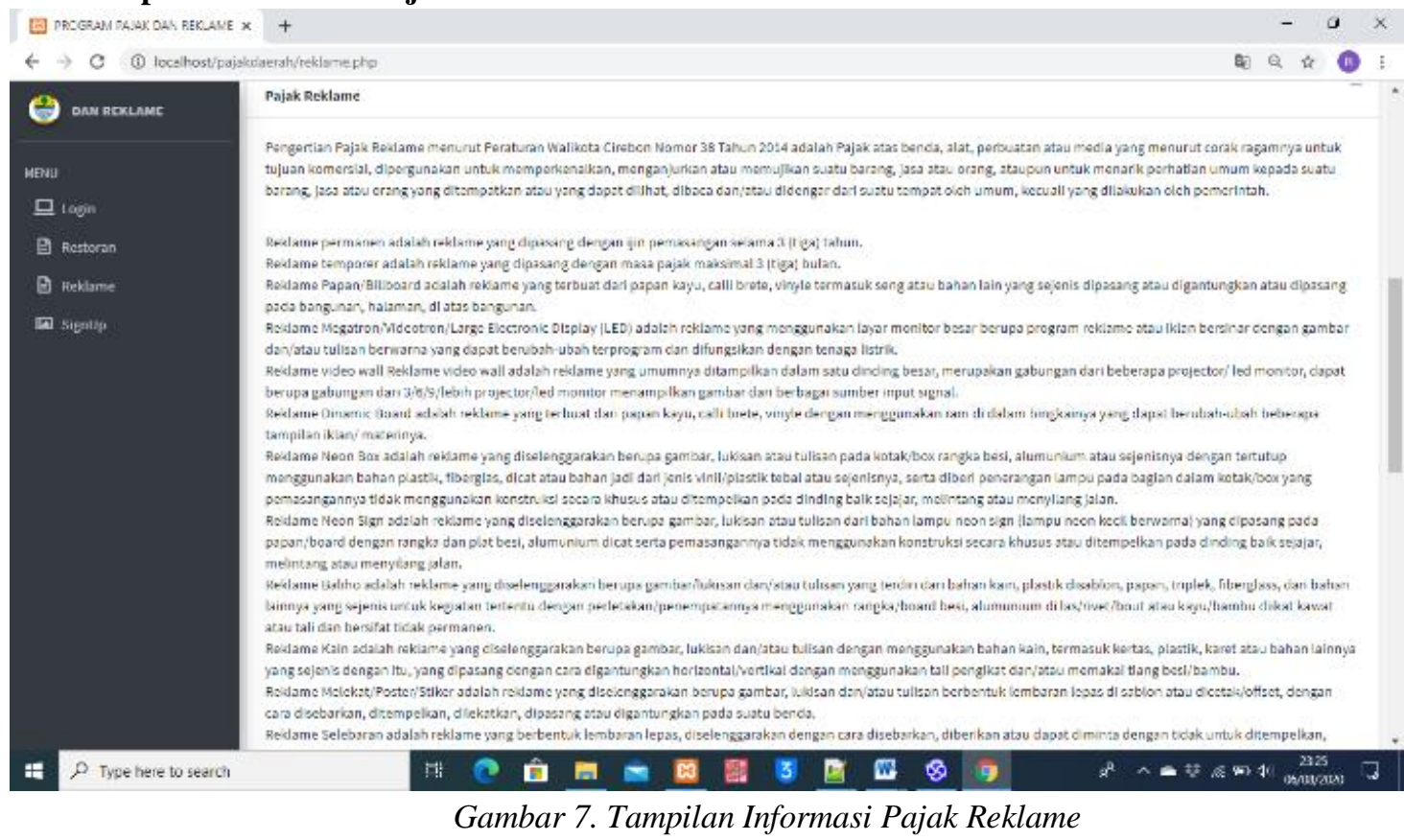

Sistem Informasi Pendataan Pajak Daerah Pada Badan Keuangan Daerah Kota Cirebon Berbasis Web Menggunakan Metode Self Assessment System -(Reza Ilyasa, Rizky Ramadhan Fatturohman) 


\subsection{Tampilan Halaman Login}

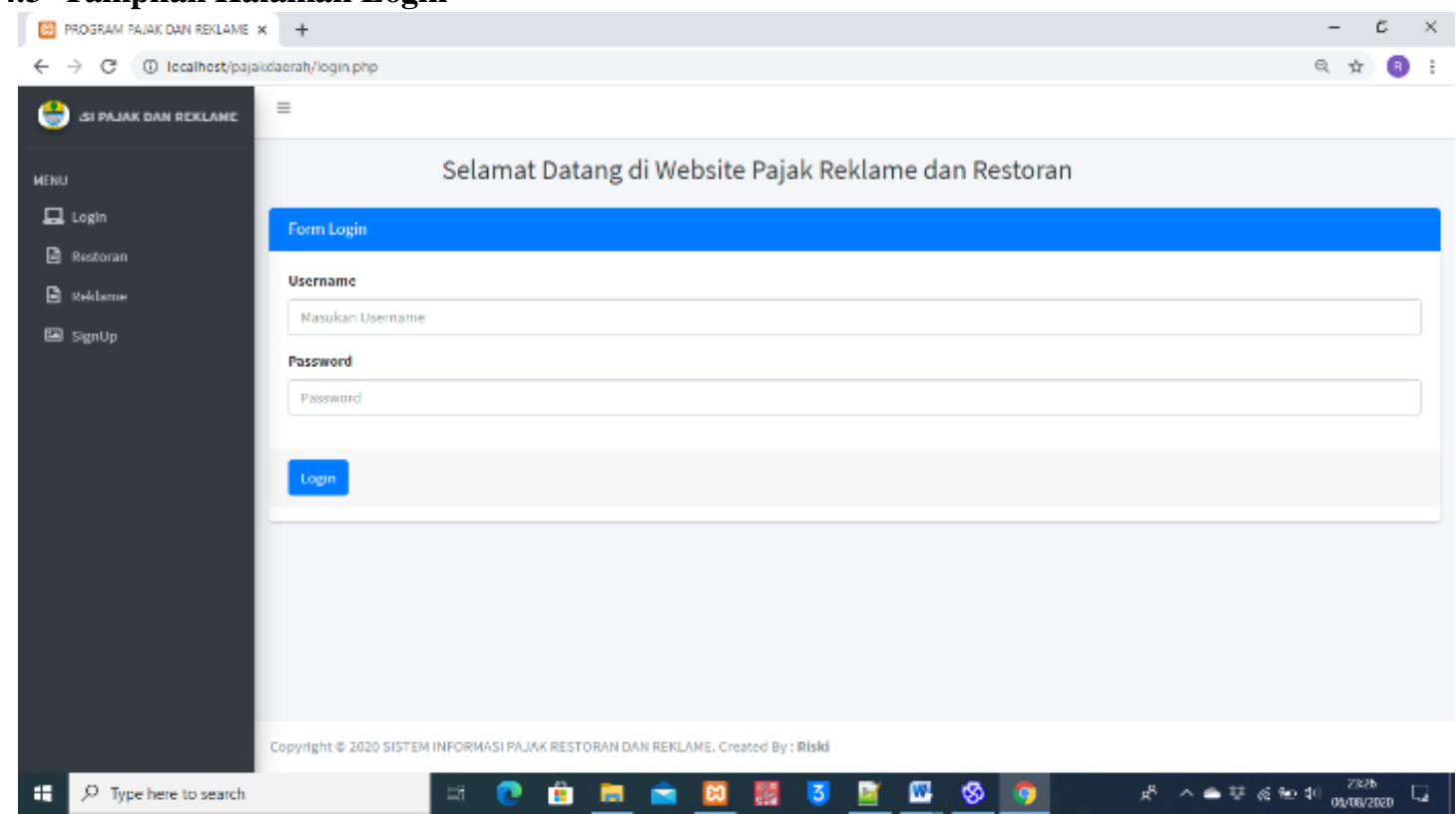

Gambar 8. Tampilan Halaman Login

\subsection{Tampilan Halaman Registrasi Login}

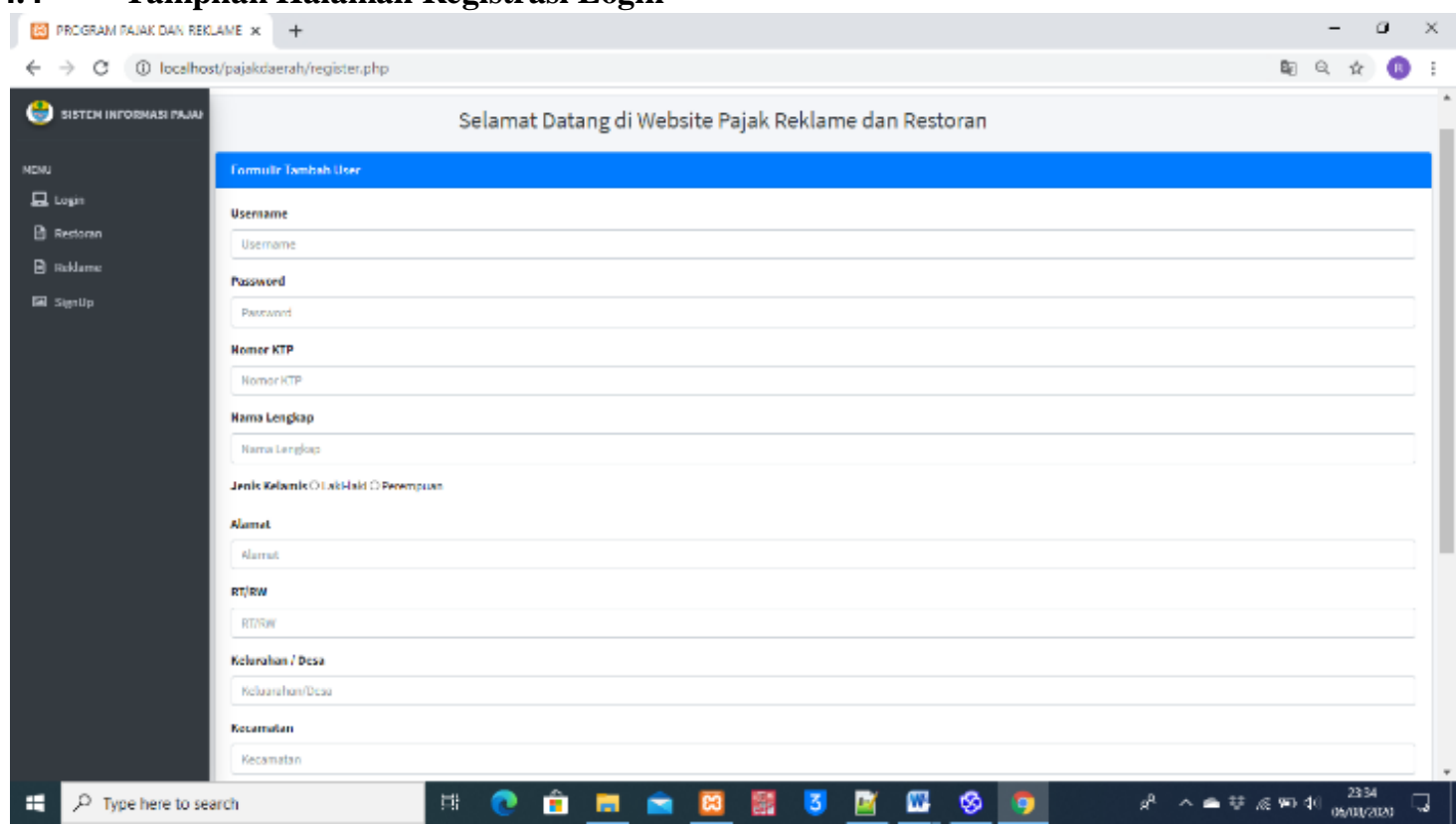

Gambar 10. Tampilan Halaman Registrasi Login 


\subsection{Tampilan Kelola Perusahaan}

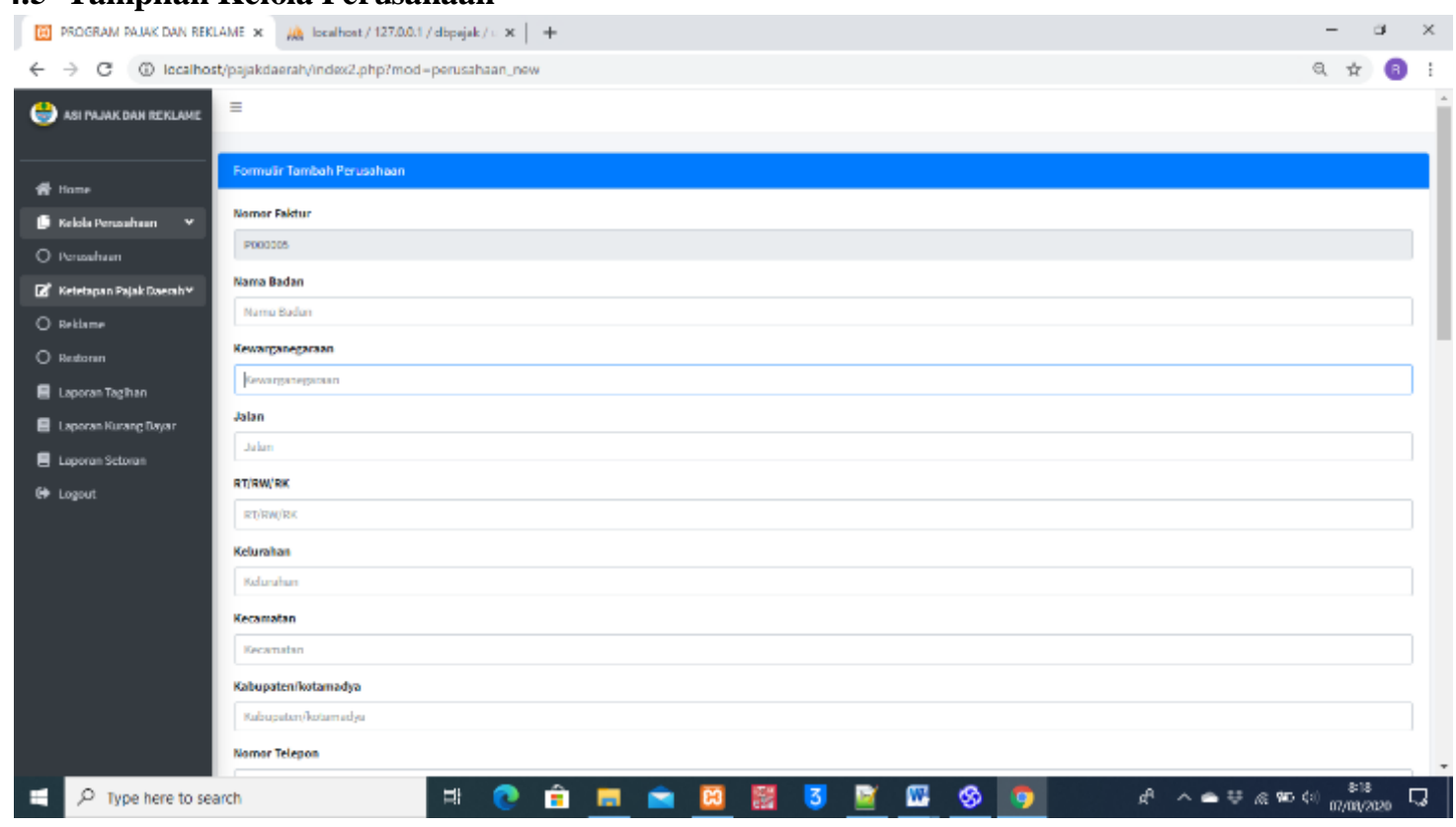

Gambar 11. Tampilan Kelola Perusahaan

\subsection{Tampilan Kelola Ketetapan Pajak Daerah}

\subsubsection{Ketetapan Pajak Reklame}

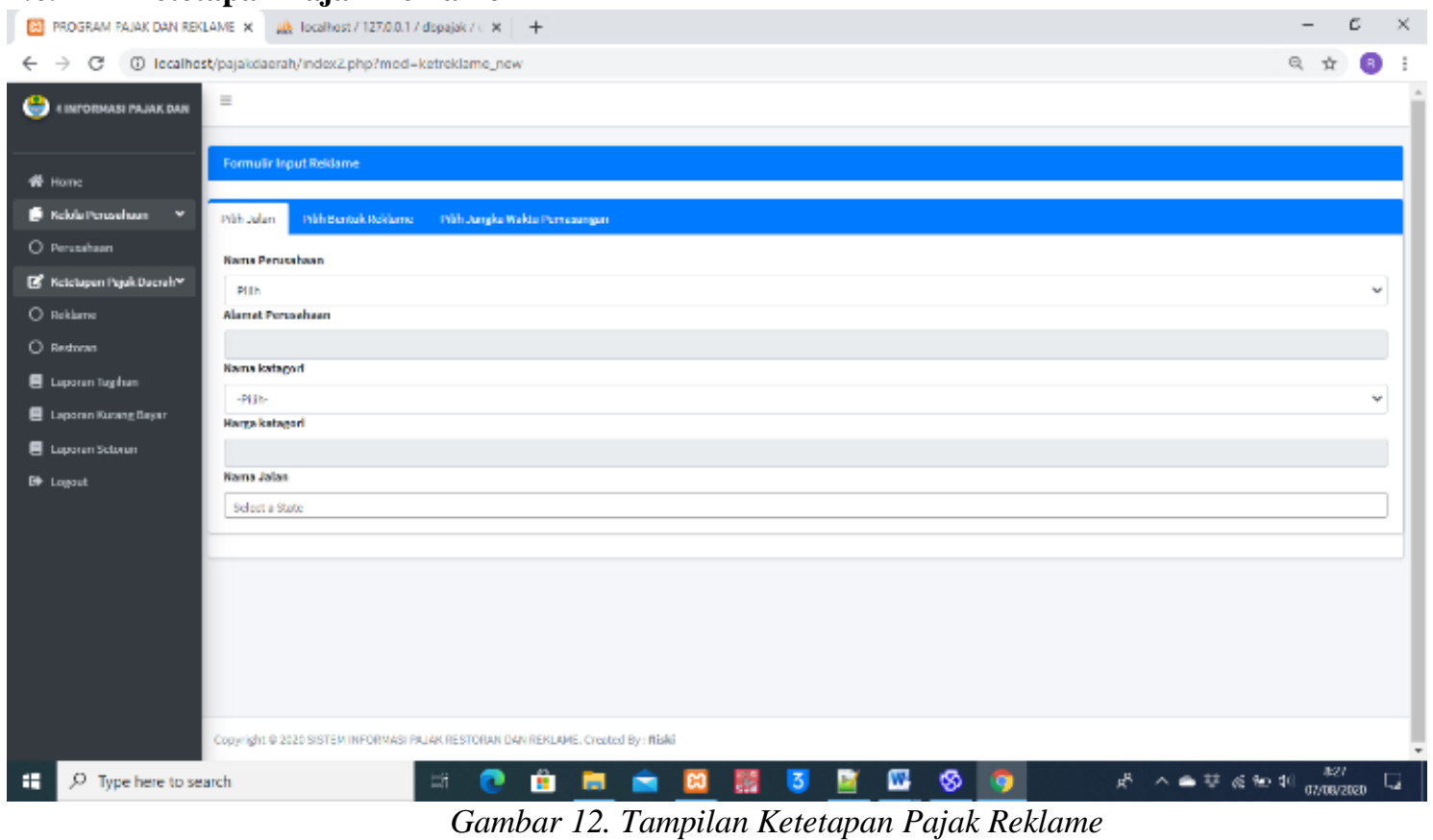

Sistem Informasi Pendataan Pajak Daerah Pada Badan Keuangan Daerah Kota Cirebon Berbasis Web Menggunakan Metode Self Assessment System -(Reza Ilyasa, Rizky Ramadhan Fatturohman) 


\subsubsection{Ketetapan Pajak Restoran}

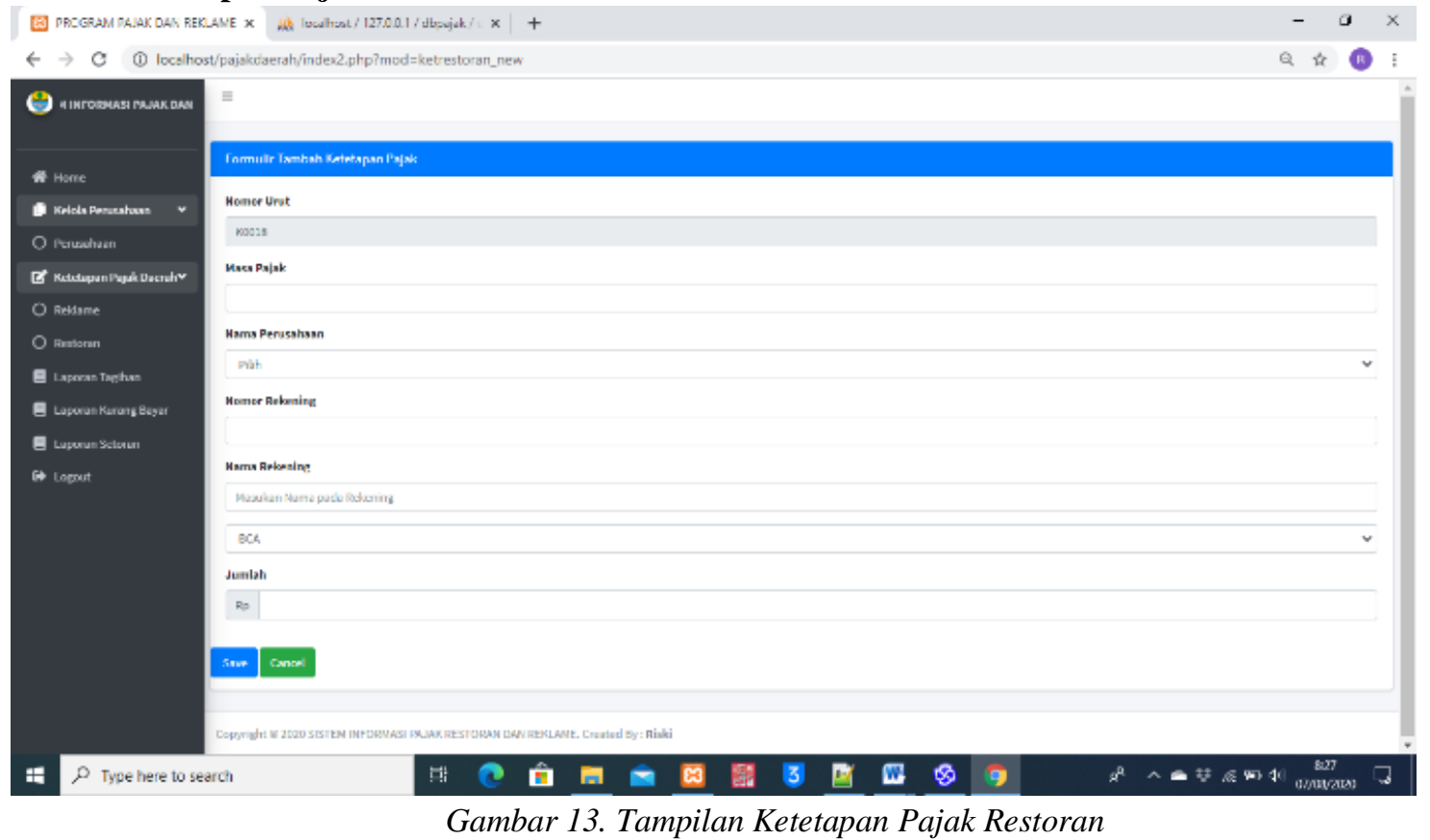

4.6.3 Tampilan Laporan Tagihan Pajak Daerah

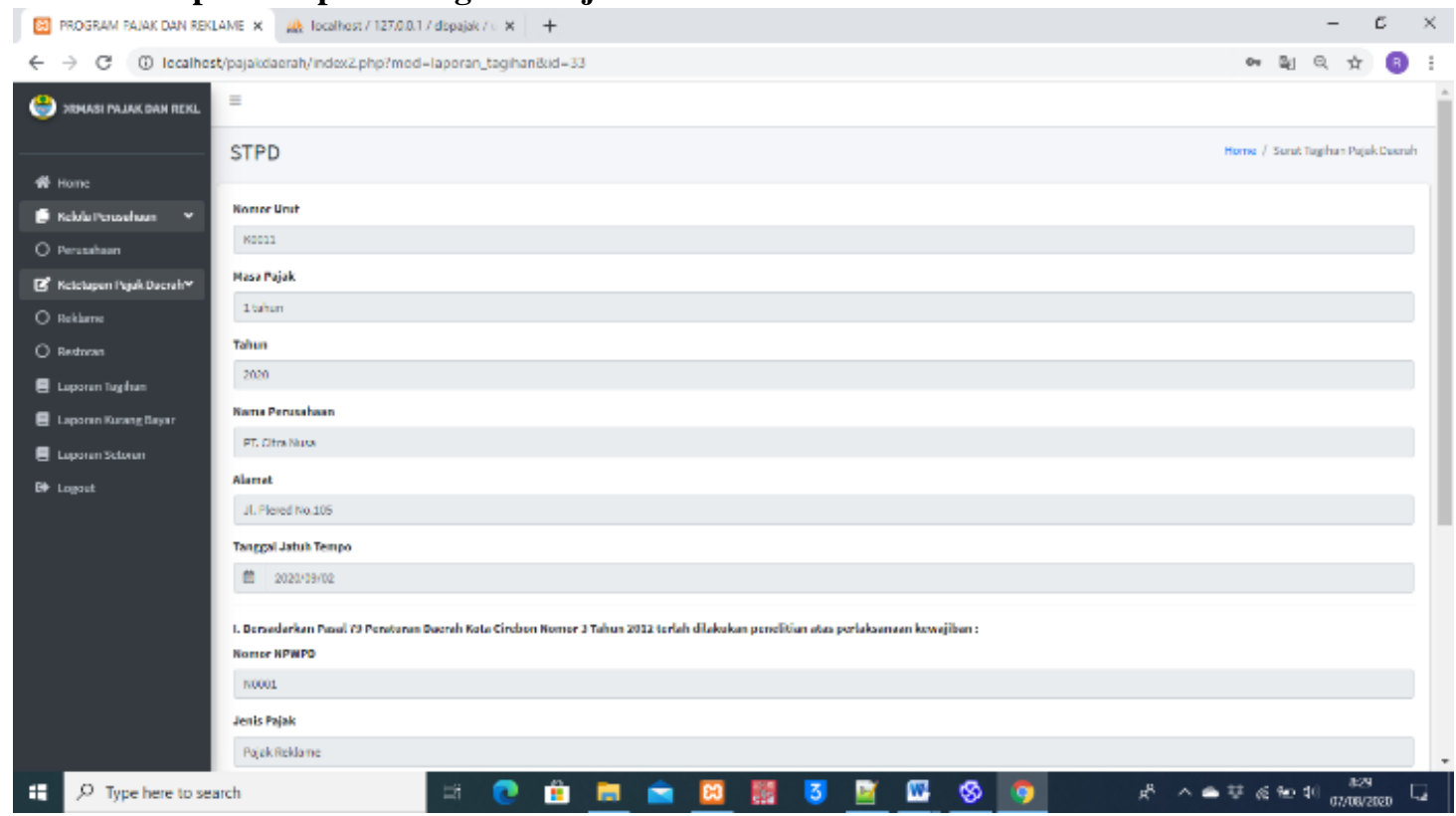

Gambar 14. Tampilan Laporan Tagihan Pajak Daerah 


\subsubsection{Tampilan Laporan Ketetapan Pajak Daerah Kurang Bayar}

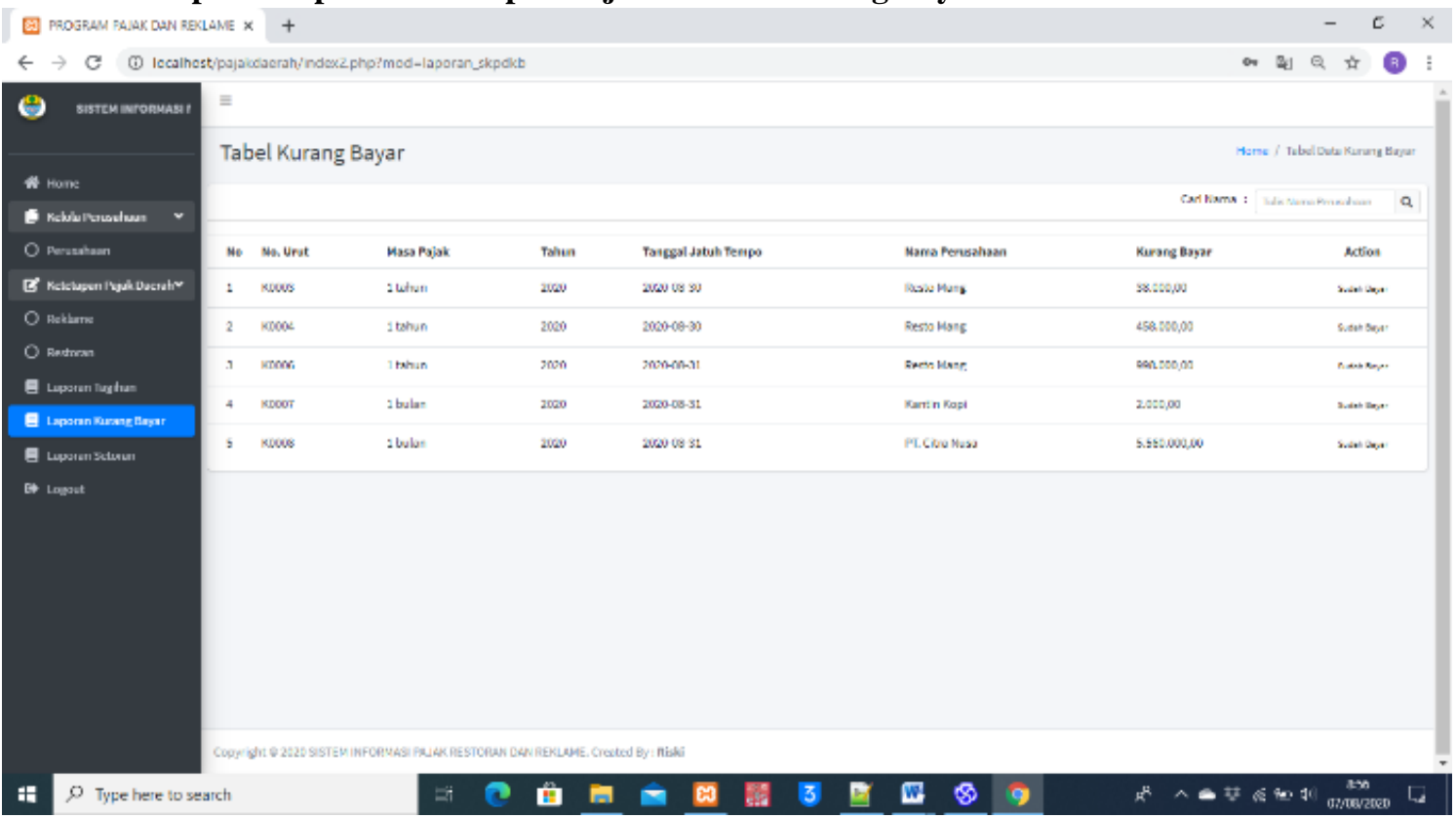

Gambar 15. Tampilan Laporan Ketetapan Pajak Daerah Kurang Bayar

\subsubsection{Tampilan Laporan Setoran Pajak Daerah}

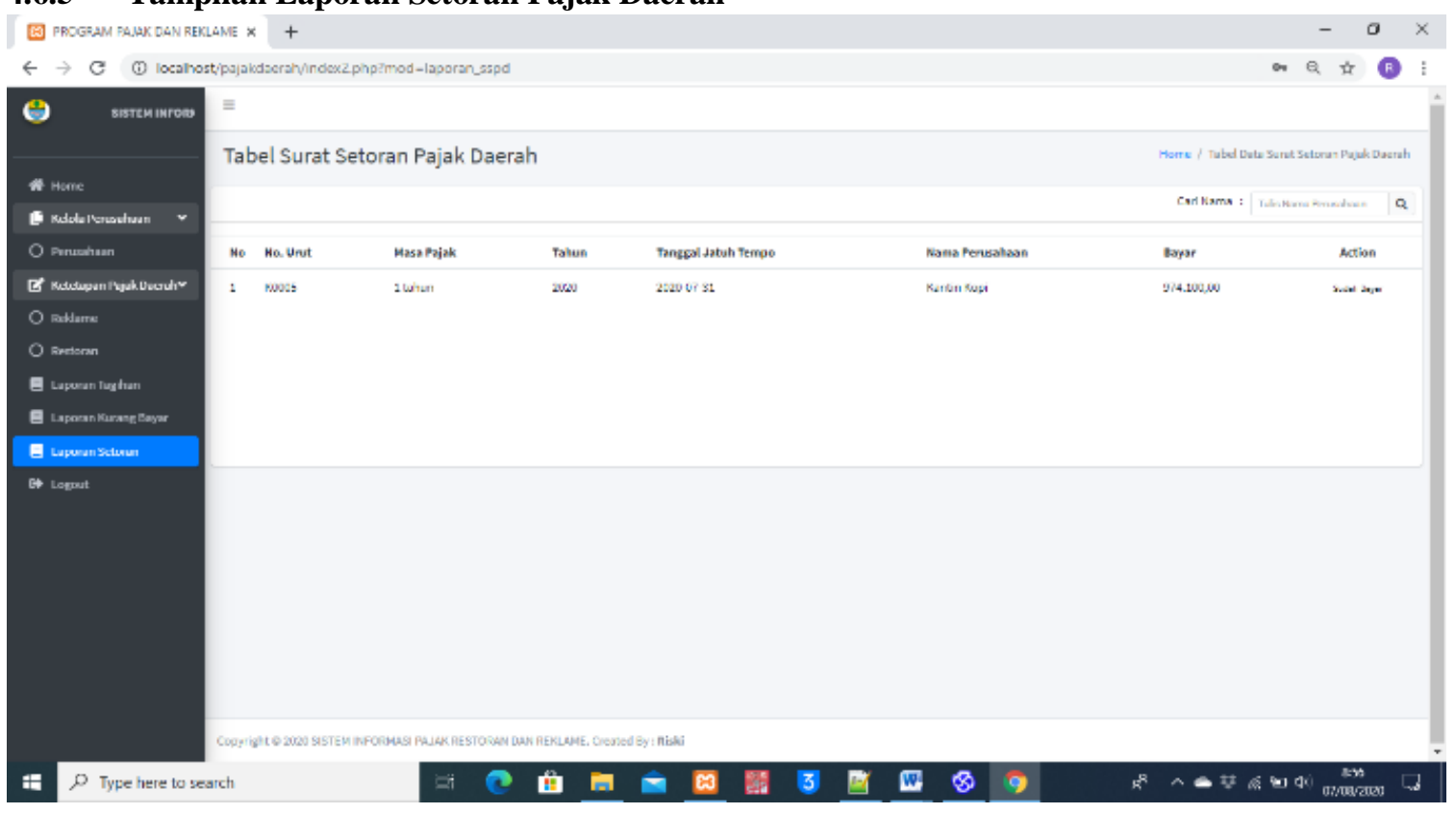

Gambar 16. Tampilan Laporan Setoran Pajak Daerah

Sistem Informasi Pendataan Pajak Daerah Pada Badan Keuangan Daerah Kota Cirebon Berbasis Web Menggunakan Metode Self Assessment System -(Reza Ilyasa, Rizky Ramadhan Fatturohman) 


\section{KESIMPULAN DAN SARAN}

\subsection{Kesimpulan}

Berikut merupakan penjabaran simpulan.

1. Dengan adanya aplikasi ini dapat mengatasi pendataan wajib pajak belum menggunakan teknologi, sehingga memudahkan petugas wajib pajak yang sering terjadi pendataan yang sama.

2. Aplikasi ini dapat merancang Sistem Informasi yang dapat mempermudah petugas wajib pajak dan Kepala Bidang Pajak Daerah dalam menerima informasi laporan.

3. Aplikasi ini merancang sistem pemungutan pajak daerah dengan menggunakan metode Self Assessment System di Badan Keuangan Daerah Kota Cirebon yang dapat membantu Wajib Pajak untuk membayar pajak.

\subsection{Saran}

Untuk mengoptimalkan atau mengembangkan sistem ini lebih lanjut sehingga di dapat suatu sistem yang lebih baik maka, ada beberapa saran yang penulis sampaikan, yaitu:

1. Seiring semakin berkembangnya teknologi modern, sebaiknya sistem informasi ini dapat dikembangkan dengan mobile apps.

2. Untuk mengembangkan aplikasi ini diharapkan ada form pemberhentian pajak restoran dan reklame

3. Sebaikknya sistem informasi ini dilengkapi dengan pesan notifikasi baik melalui email / SMS untuk informasi tagihan pajak, ketetapan pajak daerah kurang bayar, dan setoran pajak daerah.

4. Untuk pengembangan selanjutnya, sebaiknya proses pembayaran bisa otomatis dikonfirmasi oleh sistem.

\section{DAFTAR PUSTAKA}

[1] Fitriani Ayuningtyas, D. N. (2009). Evaluasi sistem pemungutan dan penyetoran pajak reklame berjalan dalam Dinas Pendapatan Daerah Kota Surakarta.

[2] Fitriani, E., Lidyah, R., \& Fajriyana, I. (2014). Pengaruh Penagihan Pajak dengan Surat Paksa Terhadap Kepatuhan Wajib Pajak, 9-10.

[3] Kacaribu, M. N. S. (2016). Prosedur Pendaftaran dan Pendataan Pajak Restoran pada Dinas Pendapatan Kota Medan.

[4] Mufidah, A., \& Susyanti, J. (2017). Analisis Pengaruh Pajak Parkir, Pajak Restoran dan Retribusi Parkir terhadap Pendapatan Asli Daerah Kota Malang (Studi Kasus Badan Pengelola Keuangan dan Aset Daerah Kota Malang). Jurnal Ilmiah Riset Manajemen, 6(02), 32-33.

[5] Nurmantu, S. (2005). Pengantar perpajakan. Yayasan Obor Indonesia.

[6] Tarjo, T., \& Kusumawati, I. (2006). Analisis Perilaku Wajib Pajak Orang Pribadi terhadap Pelaksanaan Self Assessment System: Suatu Studi di Bangkalan. Jurnal Akuntansi dan Auditing Indonesia, 10(1).

[7] Pasulu, S. R., \& Wokas, H. R. (2015). Analisis perhitungan dan pemungutan pajak restoran dan pajak hotel di dinas pendapatan daerah kota bitung. Jurnal EMBA: Jurnal Riset Ekonomi, Manajemen, Bisnis dan Akuntansi, 3(2), 1010-1011.

[8] Peraturan Daerah Kota Cirebon Nomor 2 Tahun 2004. Perubahan Atas Peraturan Daerah Kota Cirebon Nomor 3 Tahun 2012 Tentang Pajak Daerah

[9] Peraturan Wali Kota Cirebon Nomor 38 Tahun 2014. Tentang Petunjuk Pelaksaan Pajak Reklame.

[10] Wibowo, N. S. (2016). Pengaruh Pajak Restoran Terhadap Penerimaan Pad Pada Pemerintahan Daerah Kabupaten Rokan Hulu. Jurnal Mahasiswa Prodi Akuntansi Fakultas Ekonomi, 2(1). 